\title{
Integrated Law Enforcement toward Illegal Fishing in Indonesian Water Areas
}

\author{
Untung Sri Harjanto ${ }^{1}$, Diastama Anggita Ramadhan ${ }^{2}$ \\ \{hardjanto.untung@gmail.com ${ }^{1}$ \} \\ Universitas Diponegoro, Indonesia ${ }^{1,2}$
}

\begin{abstract}
Problems in the management of marine resources in Indonesian waters are mostly caused by the existence of illegal fishing, but in its enforcement are still carried out by scattered bodies as regulated in Law Number 6 of 1996 concerning Indonesian Waters which provide authority to the Indonesian Navy, National Police, and the Ministry to enforce the law in the sea area. The overlapping enforcement not only raises information on law enforcement, but also provides opportunity or bribery in the enforcement process. This has become the main foundation that as an archipelagic state, Indonesia should have implemented a water law enforcement system that is integrated by one body. The method used in this study is sociological juridical, with the hypothesis that in order to realize optimal water law enforcement, an integrated arrangement is needed to realize an effective and efficient law enforcement system.
\end{abstract}

Keywords: Illegal Fishing, Integrated Law Enforcement, Indonesian Water Area

\section{Introduction}

Republic of Indonesia is the largest archipelagic country that has great potential to become the world's maritime axis, but can also be a threat to Indonesia itself. Seeing the geographical condition of Indonesia, it becomes a necessity for the Indonesian State to be able to act more in defending its sovereign territory and safeguarding its authority from acts of transnational law violations that often occur in the boundaries of Indonesian territorial water funds. Constraints, threats or problems can arise because as a country that has very rich and diverse marine resources, it is very open to the possibility of certain parties being provoked to exploit these marine resources illegally. Especially considering that not all countries have sufficient sea for their economic interests, so they are trying to obtain natural resources from the sea illegally. This possibility can not only disrupt the stability of security at sea, but also can lead to conflict with other countries, it is even possible to become an open war between nations [1]. Border areas are areas prone to conflict between countries and the international world, therefore safeguarding sea water territories which are also national border areas is a major problem for every country, because at that limit there is added value in the form of natural resources and sovereignty.

In this regard, basically the State of Indonesia has implemented several regulations relating to the management of marine resources including fisheries, namely Act Number 6 of 1996 concerning Indonesian Waters (called the Water Act) Act Number 32 of 2009 concerning Management Environment (Environmental Law), Act Number 45 of 2009 concerning Amendments to Act Number 31 of 2004 concerning Fisheries (hereinafter referred to as 
Fisheries Law), and Act Number 12 of 2008 concerning Second Amendment to Law Number 32 of 2004 concerning Regional Government (hereinafter referred to as Regional Government Law). The regulation stipulates that the state has a large role in managing natural resources in territorial waters, especially the provisions relating to the lives of many people.

Law enforcement efforts in the Indonesian territorial waters related to illegal fishing fisheries are carried out by three competent institutions namely: the Indonesian National Navy, the Indonesian National Police and Civil Servants, all three of which have been governed by its own laws and regulations. The granting of the same authority in the case of investigating illegal fishing in the field of fisheries is the result of political compromise between the three investigating agencies. However, the political compromise is very appropriate considering it is not possible to surrender the authority of the investigation to only one investigating agency as a single investigator, with the reason: The implementation of SPDP can be understood as a mechanism for the operation of criminal law enforcement officers starting from the process of investigation, prosecution, examination in court sessions and implementation of court decisions. These four components work together to form what is known as an "integrated criminal justice system administration" and have an interdependent relationship, namely the justice system approach to criminal justice that opens up space for consultation and cooperation between subsystems. substantial synchronization includes the synchronization of laws and regulations relating to the duties and authorities of law enforcement officers and judges. For example, the synchronization of Act Number 8 of 1981 concerning the Criminal Procedure Code with other regulations, so that it is expected to provide clear guidance for law enforcement. cultural synchronization in carrying out its duties and authorities includes harmony in the mechanism of the administration of criminal justice within the framework of relations between sub-systems. In addition to the police, the investigation is also carried out by Civil Servants investigators or other investigators [2].

The basic classification form of the investigation authority in investigating illegal fishing in the field of fisheries to officers of the Indonesian Navy, Fisheries Civil Servants, and police officers of the Republic of Indonesia which contains the consequences that each investigating agency has the right to carry out illegal fishing investigations in the field of fisheries that occur in all territorial waters Indonesia, and Indonesia's Exclusive Economic Zone. These consequences raise fears of overlapping investigations of illegal fishing in the fisheries sector. In practice in the field, to avoid this, the investigation of illegal fishing in the field of fisheries is based on an "unwritten agreement" between investigators, namely that whoever knows or deserves to suspect that illegal fishing has taken place, it is he who has the right to conduct an investigation. This unwritten agreement is not without consequences because it could have occurred in the same area as there were three investigating vessels from different agencies and this meant inefficiency and resulted in suboptimal law enforcement.

\section{Material and Method}

This research was prepared using the type of normative juridical research, namely the method of legal research conducted by examining library material or secondary data. In normative legal research, written law is examined from various aspects such as aspects of theory, philosophy, comparison, consistency, general explanation and binding power of a law and the language used is legal language. The method of thinking used is the method of deductive thinking (a way of thinking in drawing conclusions drawn from something of a general nature 
that has been proven that he is right and the conclusion is intended for something of a special nature). Then strengthened with using the Statute Approach, This Statute Approach is carried out by studying the compatibility between the laws and regulations implemented in Indonesia. Then using the Historical Approach, which is an approach that is carried out by examining cases related to the legal issues at hand, and reinforced by the Conceptual Approach which is moving from an understanding of the doctrines that develop in the science of law can be a foothold to build legal arguments when resolving issues the law at hand. Reasons for using these research approaches so that later researchers can produce results of fundamental thinking in solving existing problems.

\section{Results and Discussion}

As an archipelagic state, Indonesia has a configuration to be very challenging at the same time for other countries to participate in enjoying its natural resources. Such conditions place Indonesia in an important position and role in relations with the international world as a center of gravity in the Asia-Pacific region. Indonesia's position which is located between two continents and two oceans is also not immune to high vulnerability to external threats and influences. This geographical position is widely used by outsiders who carry out prohibited or unlicensed activities in Indonesian waters especially in relation to fisheries resources. The threat of violation of the law (law transgression threat) that is not complying with national and international laws that apply in the waters of national jurisdictions including illegal fishing. To deal with certain crimes at sea like this, actually there is a body that has handled it, namely the Sea Security Agency. However, the problems in the field of fisheries as stipulated in Act Number 45 of 2009 concerning Fisheries, the institutions authorized to enforce the law as investigators are Indonesian National Navy, the Indonesian National Police and Civil Servants as stipulated in Article 73 as follows:

Article 73

(1) Investigator of criminal offenses in the field of fisheries in the area of fisheries management

(2) The Republic of Indonesia is carried out by investigators of the Civil Servants of Fisheries, Navy Officers' Investigators, and/or Police Investigators of the Republic of Indonesia.

(3) In addition to Navy investigators, the Fisheries Civil Servant Investigator has the authority to conduct investigations into criminal offenses in the field of fisheries that occur at EEZ.

(4) Investigation of criminal offenses in the field of fisheries occurring at the fishing port, preferably carried out by Investigators of the Civil Servants of Fisheries.

(5) Investigators as referred to in paragraph (1) can coordinate in the handling of investigations of speech acts in the field of fisheries. (5) To coordinate the handling of criminal acts in the fishery sector as referred to in paragraph (4), the Minister shall form a coordination forum.

Based on these provisions, it can be understood that there are institutional classifications with the scope of authority as follows: (1) The Indonesian National Police is authorized to conduct an investigation of all criminal acts in accordance with the criminal procedure code and 
other laws and regulations; (2) The Indonesian Navy also has the duty to uphold law and maintain security in the national jurisdictional sea area. (3) The Indonesian Civil Servant investigators who are given special authority by law. In addition, the authority of civil servant investigators in investigating criminal offenses in the territorial waters of the sea is also expressly stated in various statutory regulations governing both the territorial waters of Indonesia and regarding certain criminal acts in the territorial waters. Bakamla applies the Single Agency Multi Tasks system in carrying out its authority. The system, which makes Bakamla the holder of command/control over the 12 stakeholder agencies in an integrated manner, has the authority to conduct hot pursuits; stop, inspect, arrest, carry, and hand over the ship to the relevant competent authorities for the implementation of further legal processes; and integrate security and safety information systems in Indonesian waters and Indonesian jurisdictions.

Then the three institutions are coordinated through the Maritime Security Agency, which is a non-ministerial government agency under the President, which has the main task of conducting security and safety patrols in Indonesian waters and Indonesian jurisdictions. Basically, Bakamla is a revitalization of Bakorkamla, which has been strengthened by its authority, which is the central command of law enforcement in Indonesian territorial waters in contrast to Bakorkamla which only coordinates related institutions [3].

The establishment of Bakamla will shift the paradigm of law enforcement at sea from multitasked multi-agency, to multi-tasked single agency, which in practice will create effectiveness and efficiency, as well as real law enforcement. The concept of centralization like Bakamla itself has actually been practiced by several countries, such as Malaysia Maritime Enforcement Agency/MMEA, Japan Coast Guard/JCG, United States Coast Guard/USCG, and Indian Coast Guard/ICG [3]. The establishment of the Maritime Security Agency as stipulated in Act Number 32 of 2014 concerning Maritime Affairs in turn also cannot be a solution that can solve the problem of law enforcement at sea. Presidential Regulation Number 178 of 2014 the Maritime Security Agency: (1) Maritime Security Agency was formed not based as a government institution regulated through the Act; (2) The task carried out is only to conduct security and safety patrols in the territorial waters of Indonesia and the jurisdiction of Indonesia, so that it is not specific to the crime of Illegal Fishing. The authority of Bakamla is not regulated in Law Number 45 of 2009 concerning Fisheries as an investigator, so that the existence of Maritime Security Agency cannot affect the enforcement of illegal fishing law that occurs in the waters of national jurisdiction; (3) The authority held by Maritime Security Agency is to conduct an instant chase, stop, inspect, capture, carry and deliver the ship to the relevant agencies authorized for further legal processes, integrating security and safety information systems in Indonesian waters. From this authority it appears that the focus is on shipping law and security matters in general; (4) The implementation of the Maritime Security Agency task if related to the illegal fishing case will actually extend the chain of command and control because it is not regulated in Law Number 45 of 2009 concerning fisheries because the next process must be submitted to the authorized agencies namely Civil Servant Fisheries, National Police and the Navy. From the elaboration on the establishment of Bakamla, it is known that it cannot provide a solution in an effort to harmonize the implementation of fisheries law enforcement in the territorial waters of the national jurisdiction. The Ministry of Maritime Affairs and Fisheries from mid-2017 to November 2018. has handled 134 illegal fishing cases, of which 41 cases have received court decisions with permanent legal force.

Not only this problem, but there are also factors that lie behind the poor enforcement of illegal fishing waters in Indonesia, namely: 
a. Regulatory and regulatory factors starting from the process of making, implementing and supervising Policies in the field of supervision and control of illegal fishing activities are considered ineffective. The perpetrators of illegal activities are well aware that legal supervision in Indonesia is still very weak. Supported by an archipelagic state structure that makes law enforcers have many obstacles in conducting surveillance. During this time, various regulations and policies related to illegal fishing activities are attached to various sectors, so that supervision and handling are carried out very sectoral as well. Besides law enforcement officers such as the Indonesian National Police and Civil Servants, Polri and territorial guard apparatus such as the Navy, to oversee marriages with a very wide area has not been matched by maritime patrol vessels and aircraft capabilities, facilities and human resources.

b. Competency Factors of Human Resources (HR) illegal fishing law enforcement is not optimal. The reality of illegal fishing activities is clearly based on making personal/corporate profits merely by ignoring the public interest. The existence of unscrupulous officials who can be bribed in the licensing process so that it can result in an increasing number of people or corporations who want to take part in doing so, and there are also officials who not only help with licensing issues but instead protect the crimes committed by the perpetrators. These acts are often done by persons from relevant agencies that aim to seek personal gain.

c. Facilities and Infrastructure Factors Infrastructure securing the domestic market, especially in fishing ports and ships/aircraft as defense equipment in sea waters, needs to be improved. The lack of such security infrastructure is not comparable to the area of the sea that must be secured from illegal fishing violations. The ratio between the fleet of ships owned by Fisheries Civil Servant, Water Police, and the Navy is not proportional to the area and number of ports. Similar conditions also occur with the fleet of the Directorate of Water and Air Police. It is undeniable that areas prone to illegal fishing such as in the Arafuru Sea and Natuna can no longer be handled by existing illegal fishing law enforcement personnel. In this era, the ability of foreign fishing vessels is far more resilient, so that customs and security authorities are increasingly constrained in overseeing ports and vulnerable areas [4].

On that case, the threats faced by Indonesia as a state in the Southeast Asian region and ASEAN members in the form of threats of lawlessness, threats of violence, and threats to marine resources are piracy, piracy, pollution and destruction of marine ecosystems, conflicts over management of marine resources, illegal fishing and smuggling. The threat has an impact on the country's economy every year at least Rp. 300 trillion of state wealth evaporates through illegal fishing, illegal logging, illegal mining, smuggling of fuel oil, and various other illegal economic activities [5]. These problems arise due to poor maritime connectivity which results in high and most expensive logistical costs in the world and many parties carrying out activities in the Indonesian maritime region that violate statutory provisions, both nationally and internationally [6].

These problems can at least be overcome by the main basic steps in the framework of improving the law enforcement system against illegal fishing, namely through the unification of law enforcers who synergize through a coordinating system of regulation and institutions, namely Bakamla is only used as a coordinating body and the Indonesian National Navy, the Indonesian National Police and Civil Servants as law enforcement are limited to their respective scope which can be described as follows: 


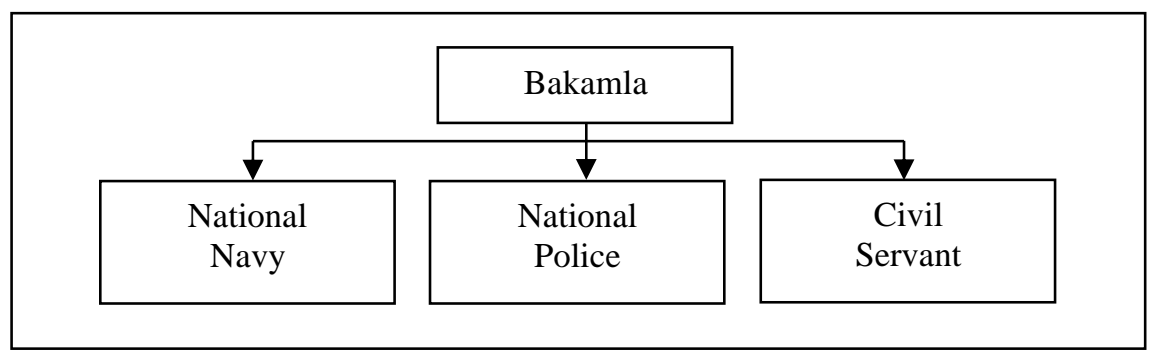

Fig. 1. Uniting Law Enforcement for Illegal Fishing.

These provisions should also be supported by other steps which are as follows, namely: (1) Mapping the problems that arise related to coordination between agencies in resolving illegal fishing. (2) Establish a joint supervisory agency tasked with overseeing the implementation of the tasks of each institution, so as to avoid the practice of abuse of authority by fisheries law enforcement officials at the level of fisheries supervisors, investigators, prosecutors and judges. (3) Integrating and synchronizing community services so that they can run quickly and without overlapping. (4) Establish cooperation and joint operational control commands and the division of operating sectors according to their respective authorities in accordance with applicable laws and regulations. (5) Building information and technology networks in order to obtain intelligence information and data relating to: potential fishery resources, ship permit administration, fisheries business licensing, shipping safety, reporting systems, and law enforcement processes. These provisions should also be supported by measures other steps are as follows, namely: (1) Mapping the problems that arise related to coordination between agencies in resolving illegal fishing. (2) Establish a joint supervisory agency tasked with overseeing the implementation of the tasks of each institution, so as to avoid the practice of abuse of authority by fisheries law enforcement officials at the level of fisheries supervisors, investigators, prosecutors and judges. (3) Integrating and synchronizing community services so that they can run quickly and without overlapping. (4) Establish cooperation and joint operational control commands and the division of operating sectors according to their respective authorities in accordance with applicable laws and regulations. (5) Building information and technology networks to obtain intelligence information and data relating to: potential fishery resources, ship permit administration, fisheries business licensing, shipping safety, reporting systems, and law enforcement processes.

\section{Conclusion}

This research produces several basic ideas, namely realizing the harmonization of each of the government's initiatives in harmony and integration in this case the Maritime Coordinating Ministry, the Ministry of Fisheries, the National Police, the Attorney General's Office, the Supreme Court, the Navy. As well as striving for the establishment and/or improvement of legislation and regulations into a legal codification product related to law enforcement in order to realize legal certainty. 


\section{Acknowledgements}

Our gratitude goes to the almighty God, and thanks those who have supported the academics at Faculty of Law Diponegoro University and the colleagues of experts in the field of research and research that can be done to find this can be resolved.

\section{References}

[1] D. H. Purnomo, "Pengamanan Wilayah Laut Indonesia,” J. Huk. Int., 2004.

[2] A. Burhanudin, "Bahan Kajian Dirjen PSDKP dalam Pelatihan. Fisheries Crime Investigation." JCLEC, Semarang, 2015.

[3] R. Samiaji, "Harmonisasi kewenangan lembaga negara dalam menanggulangi tindak pidana Illegal Fishing di perairan Indonesia," Kumpul. J. Mhs. Fak. Huk., 2015.

[4] Dirhamsyah, "Penegakan Hukum Laut di Indonesia," J. Oseana, vol. 32, no. 1, pp. 1-13, 2007.

[5] R. Dahuri, "Indonesia sebagai Poros Maritim Dunia," Media Indonesia, 2014.

[6] "Penataan Pengamanan Maritim Wilayah Maritim guna Memelihara Stabilitas Keamanan dalam Rangka Menjaga Kedaulatan NKRI," J. Kaji. Lemhannas RI, vol. 14, 2012. 